\section{Cost of RGO move to Cambridge}

SIR-There has been much discussion in your columns about the proposed move of the Royal Greenwich Observatory (RGO) from Herstmonceux to Cambridge. As I organized the main meeting in London last June, attended by many of the country's leading astronomers as well as by representatives of the Science and Engineering Research Council (SERC), I should like to comment on the present situation.

SERC intends to proceed with the move. Cambridge does not want it (as was made clear at the June meeting) and the University of Sussex does not want to lose $\mathrm{RGO}$. The move is opposed on scientific grounds by virtually all astronomers, as it would mean dismantling the archives and library, putting the telescopes out of use (which would mean that new equipment could not easily be tested) and shifting the satellite laser ranger equipment. RGO would soon lose its independence. But apart from this, there is the financial aspect.

SERC has stated that my comment that the cost would be high, and would have to be borne by the taxpayer, is "misleading". In that case, why does it not produce the actual figures? The building at Cambridge would cost at least $£ 6$ million (and is not yet authorized by the university) and the sale of Herstmonceux would not raise anything like that amount. Even in the long term, the move could not be selffinancing. This, at least, is the universal informed opinion, and one is bound to suggest that SERC is not releasing any figures simply because it does not know them.

If the move is authorized without a full, detailed knowledge of the cost involved, there will be severe repercussions, some of them political. SERC must therefore be compelled to make a proper statement if it intends to continue with the present plans.

It is, of course, possible that having realized the extent of its error of judgement, SERC is now casting around for a face-saving formula. One can only hope so, because the loss of Britain's Royal Observatory would be a scientific as well as a cultural and educational tragedy.

Patrick MoOre

Farthings, West Street,

Selsey, Sussex, UK

\section{How to verify}

SIR-In his sceptical review of Verification: How Much Is Enough?, Dennis Fakley seems to conclude that there certainly is not enough now (Nature 322, 218; 1986).

Fakley claims that verification must be concerned with demonstrating an absence of non-compliance. In other words, if it is not possible to detect with certainty every possible violation of a treaty, the treaty is, in the words of another verification sceptic, "fatally flawed". It is this type of requirement for verification that opponents of arms control hide behind.

President Kennedy defined the level of verification required as follows: the ability to detect a violation that would threaten US security in sufficient time to allow an adequate US response. This is surely a more effective definition than requiring proof of "an absence of non-compliance".

Does Fakley require the police to demonstrate that there is no crime before he feels their job is being adequately done? Arms control agreements are not religious writ to be validated absolutely. As Paul Warnke, former US arms control negotiator, said of the SALT II treaty: "We left in a little wiggle room" - in other words, disputes over minor "violations" are often differences in interpretation of a loosely worded phrase.

To claim that the Soviets are immune from international public pressure is to ignore their response to the Chernobyl disaster. Western scientists at the International Atomic Energy Agency conference in Vienna expressed satisfaction with the level of Soviet information on Chernobyl, and that is clearly due in part to the international outcry following the disaster. No country is immune from public opinion, as much as some of our leaders seem to wish it were so.

Illinois Freeze Voters,

17 N. State Street, Suite 908,

Chicago, Illinois 60602, USA

\section{Criteria of science}

SIR-R.J. Berry, professor of genetics and member of the General Synod of the Church of England, wishes his fellow scientists to consider seriously the matter of miracles ${ }^{1}$. He reminds us of the letter to The Times ${ }^{2}$ in which he and fellow believers insisted: "It is not logically valid to use science as an argument against miracles. To believe that miracles cannot happen is as much an act of faith as to believe that they can happen."

If one takes as one's measure of the criteria of science those adumbrated by Karl Popper in The Logic of Scientific Discovery ${ }^{3}$, the point made by Berry et al. ${ }^{2}$ cannot be gainsaid. There is no way that science can determine that tomorrow the Sun will not make abrupt movements and plunge zigzagging down onto people, then stop and zigzag back again, as was claimed by many thousands of eye-witnesses on 13 October 1917 at Fatima in Portugal. Curiously, equally devout Christians throughout the rest of the world did not notice this erratic behaviour of the Sun on that day.
In practice, of course, a scientist makes the assumption that the relationship of our planet to the Sun, which has been pretty uniform for the past 4,500 million years, is unlikely to change tomorrow - barring miracles, naturally. J.B.S. Haldane put the matter succinctly in the preface to his book Fact and Faith. "My practice as a scientist is atheistic. That is to say, when I set up an experiment I assume that no god, angel or devil is going to interfere with its course; and this assumption has been justified by such success as I have achieved in my professional career. I should therefore be intellectually dishonest if I were not atheist in theory, at least to the extent of disbelieving in supernatural interference in the affairs of the world. And I should be a coward if I did not state my theoretical views in public." It is useful to use the term "atheist" in the normal sense of the Greek prefix, hence "amoral", "atypical", so that "atheist" means not someone who positively asserts the nonexistence of God, but rather someone who is not a theist ${ }^{5}$.

But this is not exactly the issue for Berry et al. who "gladly accept the virgin birth, the Gospel miracles and the resurrection of Christ as historical events"2. Now, once it is claimed that an event has happened, it immediately comes into the purview of the historical sciences such as geology, palaeontology, astronomy and archaeology. These disciplines routinely deal with sequences of unique events and have developed their own methodologies for examining such events.

When a supposed unique event is described from the distant past, one of the first things a palaeontologist does is to try to find further examples in the record. Now when this is done in the case of the Resurrection, we find an embarrassment of riches. The number of religions in which the god-king dies and is resurrected three days later is legion. Christians even name this spring fertility festival Easter, after Oestre the Earth Goddess, and celebrate with such fertility symbols as eggs and rabbits.

Contrary to what Berry et al. imply, there are scientific disciplines for dealing with unique past events, and also for understanding the survival and role of ancient beliefs in modern society. Their willingness to accept the biblical miracles as "historical fact" says much for this faith but does not inspire confidence in their objectivity as scientists.

Beverly Halstead Departments of Geology and Zoology, University of Reading,

Reading RG6 $2 A B, U K$

1. Berry, R.J. Nature 322, 321-322 (1986).

2. Berry, R.J. et al. The Times 13 July 1984 p.15 (1984).

3. Popper, K.R. The Logic of Scientific Discovery (Hutchinson, London, 1959).

4. Haldane, J.B.S. Fact and Faith (Watts, London, 1934).

5. Flew, A. The Presumption of Atheism, (Elek/Pemberton, London, 1976). 